\title{
The Effect of Import Tariff Reduction on Unemployment in Indonesia: Regional Level Analysis
}

\author{
Wulan Isfah Jamil ${ }^{1}$ \\ Statistics Indonesia \\ Arie Damayanti ${ }^{2}$ \\ University of Indonesia - Indonesia
}

\begin{abstract}
The effect of import tariff reduction on unemployment can be vary not only across sectors but also across regions, yet the empirical studies on regional analysis are still limited. This study investigates the effect of tariff reduction on unemployment in districts level in Indonesia spanning period 2000-2013. We follow the strategy of Topalova to construct regional tariff exposure in districts level. Our empirical analysis use individual data approach to measure unemployment. By controlling the shifting in labor demand due to input tariff reduction, we find that impor tariff reduction leads to an increase in unemployment and the increase is higher in district with larger employment share in net importer sectors.
\end{abstract}

Keywords: urban, agricultural land, sustainable urban agricultural land, protection.

\footnotetext{
${ }^{1}$ Wulan Isfah Jamil is a staff at Statistics Indonesia (BPS) Sulawesi Tenggara and a student of Postgraduate Program in Economics, Faculty of Economics and Business, University of Indonesia. Email address: wulanisfah@gmail.com ${ }^{2}$ Arie Damayanti is a lecturer at the Postgraduate Program in Economics, Faculty of Economics and Business, University of Indonesia.
} 


\title{
Dampak Penurunan Tarif Impor terhadap Pengangguran di Indonesia: Analisis Level Regional
}

\author{
Wulan Isfah Jamil dan Arie Damayanti
}

\section{Pendahuluan}

Liberalisasi perdagangan seperti penurunan hambatan tarif impor dapat berdampak pada peningkatan pengangguran, setidaknya dalam jangka pendek. Menurut Hasan et al. (2012), dalam perekonomian terbuka dengan dua sektor dan faktor tunggal (tenaga kerja), penurunan tarif impor akan menyebabkan penurunan nilai dari marjinal produk bagi perusahaan-perusahaan lokal di sektor yang mengalami peningkatan persaingan dengan produk impor yang lebih murah di pasar domestik. Hal ini akan menyebabkan terjadinya job destruction yang membuat pengangguran di sektor ini meningkat. Di sisi lain, sektor yang paling kompetitif (sektor ekspor) akan mengalami peningkatan nilai dari marjinal produk akibat peningkatan pada harga produknya relatif terhadap harga produk di sektor pesaing impor. Hal ini menyebabkan job creation yang membuat pengangguran di sektor ini menurun. Oleh karena efek job creation membutuhkan waktu sementara efek job destruction merespon penurunan tarif impor dengan cepat, maka pengangguran secara keseluruhan akan meningkat dalam jangka pendek. Dalam hal ini, efek job destruction mendominasi efek job creation dari penurunan tarif impor.

Beberapa studi empiris dalam literatur membuktikan bahwa efek job destruction lebih tinggi dibandingkan efek job creation dari liberalisasi perdagangan seperti Casacuberta \& Gandelman (2006) dan Muendler (2010). Kedua studi ini menunjukkan bahwa pekerja yang kehilangan pekerjaannya akibat penurunan tarif impor yang terjadi di Uruguay dan Brazil tidak terserap di sektor ekspor, melainkan pindah ke sektor non-tradable, pindah ke sektor informal, atau tetap menjadi pengangguran. Temuan tersebut didukung oleh hasil dalam studi Menezes-Filho \& Muendler (2007) dan Ebenstein et al. (2009) yang menggabungkan data pekerja dan perusahaan di Brazil dan Amerika Serikat sehingga memudahkan mereka untuk menelusuri jejak pekerja formal sepanjang waktu dan antar sektor. Dengan menggunakan data individual pekerja pada periode sebelum dan sesudah liberalisasi perdagangan di Kolombia, Attanasio et al. (2004) menemukan bahwa probabilitas menjadi pengangguran secara keseluruhan meningkat, meski peningkatannya lebih didominasi di sektor nontradable.

Akan tetapi, studi-studi tersebut memanfaatkan variasi kebijakan tarif di level sektoral dalam menganalisis dampak liberalisasi perdagangan. Sementara itu, dampak liberalisasi perdagangan tidak hanya dapat bervariasi antar sektor, tetapi juga dapat bervariasi antar daerah karena perbedaan komposisi tenaga kerja di tiap sektor antar daerah (Goldberg \& Pavcnik, 2016). Oleh karena trade shock seperti liberalisasi perdagangan bekerja pada general equilibrium, maka perlu untuk memetakan shock yang terjadi di banyak sektor secara empiris ke level yang lebih agregat seperti level regional. Dengan analisis dampak liberalisasi perdagangan di level regional, kita tidak hanya dapat mengatasi masalah degree-of-freedom yang dapat terjadi pada analisis di level agregat nasional dan dampaknya secara keseluruhan di tiap daerah, tetapi juga perbedaan dampaknya antar daerah. Sejumlah studi empiris 
dalam literatur telah membuktikan adanya perbedaan dampak liberalisasi perdagangan antar daerah seperti Topalova (2007, 2010), Kis-Katos \& Sparrow (2011, 2015), dan Kovak (2013). Literatur ini tidak hanya menyoroti perbedaan komposisi tenaga kerja di tiap sektor antar daerah, tetapi juga adanya friksi dalam mobilitas pekerja antar daerah untuk dapat mengidentifikasi perbedaan dampak liberalisasi antar daerah.

Meski literatur terkait dampak liberalisasi perdagangan di level regional cukup banyak, tetapi studi yang menghubungkan liberalisasi perdagangan, khususnya penurunan tarif, dan pengangguran di level regional masih terbatas. Salah satunya adalah studi Hasan et al. (2012) yang melakukan analisis dampak liberalisasi perdagangan di India pada level state untuk melengkapi analisisnya di level industri. Dengan mengadopsi strategi pengukuran regional tariff exposure Topalova (2007), studi ini membangun ukuran proteksi, termasuk tarif, di level state. Meski hasil estimasinya belum dapat membuktikan adanya peningkatan pengangguran akibat penurunan tarif secara keseluruhan, mereka menemukan bahwa state dengan pasar tenaga kerja yang lebih fleksibel atau memiliki alokasi pekerja yang besar di sektor net exporter mengalami penurunan pada unemployment rate. Atau dengan kata lain, states tersebut kurang terekspos terhadap penurunan tarif yang terjadi di India.

Berbeda dengan studi Hasan et al. (2012), Dix-Carneiro \& Kovak (2017) menggunakan pendekatan data individu dalam menganalisis dampak penurunan tarif impor di Brazil terhadap tingkat pengangguran di level regional. Tingkat pengangguran di level regional diestimasi dari data individu sehingga estimasinya dilakukan dengan regresi dua tahap. Strategi ini mirip dengan strategi estimasi dalam studi Attanasio et al. (2004), hanya saja mereka menganalisis di level regional. Pengukuran regional tariff exposure dalam studinya mengikuti strategi Kovak (2013) yang menambahkan adjustment pada metode pengukuran Topalova dengan informasi elastisitas permintaan tenaga kerja di tiap sektor tradable di suatu daerah. Hasil estimasi regresi tahap keduanya menunjukkan bahwa daerah yang lebih terekspos terhadap penurunan tarif impor mengalami peningkatan pengangguran yang lebih besar dibandingkan daerah lainnya.

Studi empiris yang menghubungkan tarif dan pengangguran di Indonesia pernah dilakukan oleh Ihsanuddin (2015), tetapi analisisnya dilakukan di level sektoral sementara analisis level regional sejauh ini belum pernah dilakukan di Indonesia. Indonesia sendiri telah mengalami liberalisasi perdagangan sejak tahun 1980-an yang melibatkan penurunan pertama pada tarif impor dan tarifikasi yang lambat di saat yang bersamaan (Kis-Katos \& Sparrow, 2015). Indonesia kembali harus menurunkan tarif impornya setelah terjadi krisis finansial Asia di tahun 1997/1998, dimana IMF merekomendasikan Indonesia untuk menurunkan tarif impornya dalam rangka pemulihan paska krisis. Setelah tahun 2000, tarif impor masih terus mengalami penurunan meski penurunannya tidak sebesar sebelumnya. Sementara itu, meski tingkat pengangguran di Indonesia mengalami tren penurunan, tetapi angkanya masih tergolong tinggi. Dengan terus meningkatnya populasi usia kerja di Indonesia, persaingan untuk mendapatkan pekerjaan di antara mereka juga akan meningkat. Berdasarkan teori, penurunan tarif impor diperkirakan dapat mempengaruhi tingkat pengangguran dan dampaknya akan berbeda-beda antar daerah. Sejauh ini, prediksi tersebut belum diuji di Indonesia.

Penelitian ini bertujuan untuk mengestimasi dampak penurunan tarif impor terhadap tingkat pengangguran pada level kabupaten/kota di Indonesia dengan menggunakan 
data Survei Angkatan Kerja Nasional (Sakernas) selama periode 2000-2013. Meski jumlah kabupaten/kota di Indonesia cukup banyak sehingga dapat memberikan variasi observasi yang banyak dibandingkan level provinsi, tetapi data Sakernas belum dapat digunakan untuk estimasi di level kabupaten/kota. Oleh karena itu, penelitian ini menggunakan inflation factor yang tersedia pada datanya. Pengukuran regional tariff exposure di level kabupaten/kota mengikuti strategi Topalova (2007) yang umum digunakan dalam literatur. Pengangguran dalam penelitian ini didekati dengan data individu yaitu resiko menjadi pengangguran di suatu kabupaten/kota relatif terhadap rata-rata kabupaten/kota. Dengan demikian, estimasi dampak penurunan tarif impor terhadap tingkat pengangguran di level kabupaten/kota dalam penelitian ini dilakukan dengan regresi dua tahap, yaitu dengan metode restricted least square pada regresi tahap pertama dan metode weighted least square pada regresi tahap kedua dengan varians dari estimasi tahap pertama sebagai penimbangnya.

Sama seperti temuan dalam studi Hasan et al. (2012), penelitian ini tidak menemukan bukti adanya hubungan antara tarif impor dengan pengangguran. Hal ini kemungkinan disebabkan adanya mixed effect dari penurunan tarif terhadap pengangguran. Setelah mengontrol dampak penurunan tarif pada input yang tidak diproduksi di pasar domestik, penelitian ini kemudian menemukan adanya hubungan negatif antara penurunan tarif impor dengan pengangguran secara keseluruhan. Peningkatan tersebut lebih besar pada kabupaten/kota yang memiliki alokasi tenaga kerja yang tinggi pada sektor yang paling terekspos terhadap penurunan tarifnya. Hal ini konsisten dengan teori dan sejalan dengan temuan dalam studi Dix-Carneiro \& Kovak (2017) dengan kasus di Brazil.

\section{Tinjauan Literatur}

\subsection{Tinjauan Teoretis}

Untuk dapat menjelaskan dampak penurunan tarif impor pada pengangguran, penelitian ini meminjam kerangka teori dalam studi Hasan et al. (2012). Mereka menggabungkan model standar perdagangan dalam kerangka Ricardian dengan model searchgenerated unemployment. Dalam modelnya, terdapat satu produk akhir dan dua input antara. Produk akhir merupakan produk non-tradable dan dianggap sebagai numeraire sementara input antara merupakan produk tradable. Produk akhir dihasilkan dengan menggunakan kedua input antara tersebut. Tenaga kerja merupakan satu-satunya faktor produksi untuk input antara. Pasar tenaga kerjanya sesuai dengan model job search oleh Pissarides (2000) dengan dua sektor. Satu unit input antara yang dihasilkan merupakan satu match antara pekerjaan dan pekerja. Match antara keduanya akan terbentuk dengan rate yang ditentukan dengan fungsi matching antara dua ukuran partisipasi pasar tenaga kerja, yaitu vacancy dan pengangguran. Ketika satu pekerjaan match dengan seorang pekerja, match tersebut akan terus bertahan hingga keduanya terpisah oleh suatu idiosyncratic shock.

Penelitian ini membutuhkan tiga persamaan dari model Hasan et al. (2012) tersebut untuk menjelaskan hubungan antara tarif dan pengangguran. Ketiga persamaan tersebut adalah sebagai berikut: 


$$
\begin{aligned}
& p_{i} h_{i}-w_{i}-\lambda_{i} F_{i}=\frac{\delta_{i}\left(\rho+\lambda_{i}\right)}{m_{i} \theta_{i}^{\gamma-1}} \\
& w_{i}=(1-\beta) b+\beta\left(p_{i} h_{i}+\delta_{i} \theta_{i}-\lambda_{i} F_{i}\right) \\
& u_{i}=\frac{\lambda_{i}}{\lambda_{i}+m_{i} \theta_{i}^{\gamma}}
\end{aligned}
$$

dimana: $p_{i}$ adalah harga produk pada sektor- $i$ dalam term produk akhir; $h_{i}$ adalah parameter teknologi pada sektor- $i$ dalam term produk akhir untuk menangkap produktivitas tenaga kerja; $w_{i}$ adalah upah pada sektor- $i$ dalam term produk akhir; $\lambda_{i}$ adalah arrival rate of shock yang menyebabkan job destruction pada sektor- $i$ dalam term produk akhir; $F_{i}$ adalah firing cost pada sektor- $i$ dalam term produk akhir; $\delta_{i}$ adalah biaya rekrutmen pada sektor- $i$ dalam term produk akhir; $\rho$ adalah exogenous discount factor; $m_{i}$ adalah parameter skala dalam fungsi matching pada sektor- $i$ dalam term produk akhir; $\theta_{i}$ adalah market tightness pada sektor- $i$ dalam term produk akhir yang diukur dengan rasio dari vacancy rate terhadap tingkat pengangguran; $y$ adalah parameter intensitas vacancy; $\beta$ adalah bargaining power bagi pekerja; $b$ adalah benefit menjadi pengangguran dalam term produk akhir; dan $u_{i}$ adalah tingkat pengangguran pada sektor- $i$ dalam term produk akhir. Persamaan (1), (2), dan (3) sama dengan persamaan (22), (23), dan (24) dalam studi Hasan et al. (2012).

Dengan mengeliminasi $w_{i}$ pada persamaan (1) dan (2), kita peroleh,

$$
p_{i}=\frac{1}{h_{i}}\left[b+\lambda_{i} F_{i}+\frac{\beta}{1-\beta} \delta_{i} \theta_{i}+\frac{\delta_{i}\left(\rho+\lambda_{i}\right)}{(1-\beta) m_{i} \theta_{i}^{\gamma-1}}\right]
$$

Dari persamaan (3) dan (4), kita dapatkan hubungan tidak langsung antara tingkat pengangguran dan harga produk pada suatu sektor, yaitu:

$$
\frac{\partial u_{i}}{\partial p_{i}}=\frac{\partial u_{i}}{\partial \theta_{i}} \cdot \frac{\partial \theta_{i}}{\partial p_{i}}=\frac{-\gamma \lambda_{i} m_{i} \theta_{i}^{\gamma-1}}{\left(\lambda_{i}+m_{i} \theta_{i}^{\gamma}\right)^{2}} \cdot \frac{(1-\beta) h_{i}}{\delta_{i}\left[\beta+\frac{(1-\gamma)\left(\rho+\lambda_{i}\right) \theta_{i}^{-\gamma}}{m_{i}}\right]}<0
$$

Relasi (5) menunjukkan hubungan negatif antara tingkat pengangguran dan harga produk di suatu sektor yang berarti ketika terjadi penurunan harga produk di suatu sektor akan menyebabkan tingkat pengangguran di sektor tersebut.

Kita juga dapat menggunakan relasi (5) untuk menjelaskan hubungan antara tarif impor dan tingkat pengangguran di suatu sektor. Ketika pemerintah menurunkan tarif impor di suatu sektor, produk di sektor tersebut akan mengalami peningkatan persaingan dengan adanya produk impor yang lebih murah pada pasar domestik. Perusahaan-perusahaan lokal di sektor tersebut akan menurunkan harga produknya agar tetap dapat bersaing dengan produk impor di pasar domestik. Harga yang lebih rendah membuat nilai tambahan output dari tiap penambahan satu unit tenaga kerja (marjinal produk dari tenaga kerja) menurun, sehingga perusahaan lokal di sektor ini mengurangi permintaaannya terhadap tenaga kerja. Jumlah vacancy akan berkurang yang berarti market tightness di sektor ini juga akan menurun. Pada akhirnya, tingkat pengangguran di sektor ini akan meningkat. Ketika penurunan tarif terjadi di banyak sektor, maka akan dampaknya pada peningkatan tinggi pengangguran akan berbeda-beda degree-nya tergantung pada tingkat eksposure di masing-masing sektor. 
Sementara itu, penurunan harga produk di sektor pesaing impor dapat menyebabkan peningkatan pada harga relatif produk di sektor kompetitif (sektor ekspor). Peningkatan harga relatif tersebut menyebabkan nilai marjinal produk dari tenaga kerja akan meningkat. Hal ini dapat mendorong perusahaan di sektor ekspor meningkatkan permintaannya terhadap tenaga kerja sehingga terjadi job creation. Akan tetapi, efek job creation ini membutuhkan waktu tidak seperti efek job destruction yang langsung merespon penurunan tarif impor sehingga efek job destructionakanmendominasidalamjangkapendek.Selainitu,peningkatan produktivitastenaga kerja pada sektor ekspor ini juga dapat menyebabkan perusahaan tidak perlu lagi menambah tenaga kerjanya sehingga efek job destruction tetap akan lebih tinggi dari efek job creation.

Akan tetapi, hubungan negatif antara tarif impor dan tingkat pengangguran, relasi (5), hanya berlaku pada sektor-sektor dimana perusahaannya menghadapi peningkatan persaingan dengan produk impor yang lebih murah di pasar domestik (dampak penurunan tarifoutput). Sementara itu, akan ada sektor yang menerima benefit dari penurunan tarifimpor, yaitu sektor yang menggunakan input yang tidak diproduksi oleh perusahaan lokal sehingga harus mengimpor inputnya (dampak tarif input). Perusahaan-perusahaan lokal pada sektor ini dapat mengalami peningkatan profit karena biaya input yang lebih murah. Peningkatan profit ini dapat mendorong perusahaan lokal untuk melakukan ekspansi usahanya sehingga menyebabkan job creation. Hal ini menyebabkan employment meningkat dan pengangguran menurun. Selain itu, peningkatan profit tersebut juga dapat menarik perusahaan-perusahaan lokal baru untuk masuk ke pasar. Dalam hal ini, job creation juga akan meningkat sehingga employment meningkat dan penganggurannya menurun. Peningkatan profit juga dapat mendorong perusahaan menaikkan upah yang dibayarkan untuk pekerjanya. Hal ini tentunya dapat menyebabkan pergeseran pada labor demand sehingga pengangguran akan menurun. Dengan demikian, penurunan tarif input dapat berdampak pada penurunan pengangguran

Oleh karena data ketenagakerjaan di level regional hanya tersedia hinggal level 1-digit atau 2-digit sektor, hal ini tidak memungkinkan untuk memisahkan penurunan tarif input dan penurunan tarif output sehingga penelitian ini hanya dapat fokus pada dampak penurunan tarif secara keseluruhan dimana semua tarif dianggap sebagai tarif output. Meskipun demikian, dampak penurunan tarif input tetap dapat berimplikasi pada hasil estimasi dampak penurunan tarif secara keseluruhan sehingga perlu dikontrol. Hal ini akan dibahas lebih lanjut dalam pembentukan persamaan empirisnya.

Sementara itu, kebijakan perdagangan seperti tarif impor yang diimplementasikan pada level nasional dapat memberikan dampak yang berbeda pada labor market outcomes antar daerah. Pasar tenaga kerja di tiap daerah berbeda-beda dalam hal komposisi ketenagakerjaan sektoral sebelum terjadinya perubahan tarif. Daerah yang memiliki alokasi tenaga kerja yang besar pada sektor yang paling terkespos terhadap penurunan tarif impor, juga akan lebih terekpos terhadap penurunan tarifnya. Berdasarkan relasi (5), kita dapat mengatakan bahwa daerah yang memiliki alokasi tenaga kerja yang relatif lebih besar pada sektor yang paling terekspos terhadap penurunan tarif, akan mengalami peningkatan pengangguran yang lebih tinggi dibandingkan daerah lainnya. Dalam hal ini, sektor net importer digunakan untuk mewakili sektor yang paling terekspos terhadap penurunan tarif impor karena impor lebih mendominasi di sektor ini. Penelitian ini mendefinisikan suatu sektor sebagai net importer jika nilai net export-nya kurang dari nol. Perbedaan dampak penurunan tarif terhadap tingkat pengangguran antar daerah ini hanya dapat diidentifikasi dengan mobilitas pekerja 
antar daerah yang terbatas. Jika mobilitas pekerja antar daerah tinggi, maka pekerja yang kehilangan pekerjaan di daerah yang lebih terekspos terhadap penurunan tarif impor dapat dengan mudah pindah ke daerah yang kurang terespos terhadap penurunan tarif impornya (Autor, Dorn, \& Hanson, 2013).

\subsection{Tinjauan Empiris}

Berbeda dengan literatur teoretisnya yang cukup berkembang, studi empiris dalam literatur terkait dampak dari liberalisasi perdagangan terutama dampak penurunan tarif impor terhadap pengangguran tidak banyak. Salah satu diantaranya adalah studi yang dilakukan oleh Dutt et al. (2009). Dutt et al. menggunakan data berbagai ukuran kebijakan perdagangan termasuk tarif dan unemployment rate dari 90 negara serta berbagai karakteristik negara sampelnya sebagai variabel kontrol untuk menganalisis dampak liberalisasi perdagangan terhadap pengangguran. Analisis yang dilakukan adalah analisis cross-sectional di tahun 1990 dan analisis data panel selama periode tahun 1985 hingga 2004. Analisis cross-sectionalnya membenarkan prediksi Ricardian dari modelnya yaitu bahwa proteksi perdagangan termasuk tarif berkorelasi positif dengan pengangguran. Atau dengan kata lain, penurunan tarif berdampak pada penurunan unemployment rate. Sementara itu, analisis data panelnya menemukan bahwa liberalisasi perdagangan menyebabkan peningkatan pada unemployment rate dalam jangka pendek. Unemployment rate mulai menurun setelah lag 1 dan 2 . Secara keseluruhan, liberalisasi perdagangan berdampak pada penurunan unemployment rate dalam jangka panjang.

Akan tetapi, studi Dutt et al. (2009) tidak dapat menjelaskan variasi dampak dari liberalisasi perdagangan di dalam suatu negara. Hasan et al. (2012) berargumen bahwa tiap negara memiliki karakteristik masing-masing yang tidak selalu dapat dikontrol pada saat estimasi model regresi seperti dalam studi Dutt et al. (2009). Untuk itu, beberapa akademisi melakukan studi yang mempelajari dampak dari liberalisasi perdagangan terhadap unemployment pada suatu negara, seperti studi Attanasio et al. (2004) dan Hasan et al. (2012). Pada dasarnya, studi Attanasio et al. (2004) bertujuan untuk meneliti dampak dari penurunan tarif yang terjadi di Kolombia pada tahun 1980-an dan 1990-an terhadap ketimpangan upah melalui tiga mekanisme yaitu meningkatnya returns terhadap pendidikan tingkat perguruan tinggi, perubahan dalam upah sektoral yang dapat merugikan bagi sektor yang pada awalnya berupah rendah serta padat akan pekerja tidak terampil, serta melalui pergeseran angkatan kerja ke sektor informal yang biasanya upahnya rendah dan tidak menawarkan benefit apapun pada pekerjanya. Akan tetapi, Attanasio et al. (2004) juga melakukan pengecekan apakah peningkatan dalam probabilitas menjadi pengangguran bagi pekerja yang bekerja di sektor tradable lebih besar dibandingkan pekerja yang memiliki karakteristik yang sama tetapi bekerja di sektor non-tradable. Hal ini dikarenakan pengangguran dapat menjadi suatu komponen yang penting dari mekanisme penyesuaian pasar tenaga kerja terhadap shock dalam perdagangan. Oleh karena keterbatasan data, pengecekan hanya dilakukan pada setahun sebelum dan sesudah penurunan tarif. Regresinya dilakukan pada variabel indikator status kerja individu (bekerja atau tidak bekerja), variabel dummy sebelum dan sesudah penurunan tarif impor, serta karakteristik dari pekerja. Hasil estimasinya menunjukkan bahwa peningkatan probabilitas pekerja di sektor tradable untuk menjadi penganguran ternyata tidak lebih besar dibandingkan pekerja yang bekerja di sektor non-tradable. 
Mengikuti studi Attanasio et al. (2004), Hasan et al. (2012) juga menganalisis dampak liberalisasi perdagangan terhadap pengangguran di level sektoral dengan menggunakan data afiliasi sektor dari individu dan beberapa indikator proteksi perdagangan di India termasuk tarif pada periode 1993-2004. Estimasinya dilakukan dengan dua tahap. Estimasi pada persamaan regresi pertama dilakukan dengan menggunakan data individu yang memiliki pengalaman kerja di sektor tertentu. Variabel penjelasnya merupakan karakteristik individu seperti umur, jenis kelamin, pendidikan, afiliasi sektor, dan tempat tinggal. Estimasinya dilakukan secara terpisah tiap tahun observasinya. Hasil estimasi koefisien sektor kemudian dinormalisasi dengan prosedur restricted least square seperti dalam studi Attanasio et al. (2004) yang diinterpretasikan sebagai probabilitas menjadi pengangguran di suatu sektor relatif terhadap rata-rata probabilitasnya di semua sektor. Indikator ini dapat digunakan untuk mendekati ukuran relative unemployment rate. Koefisien sektor yang telah dinormalisasi dijadikan variabel dependen untuk persamaan regresi kedua dengan variabel tarif (lag satu tahun). Estimasinya dilakukan pada level first difference untuk mengatasi masalah endogenitas. Hasil estimasi pada persamaan regresi kedua dengan metode WLS menunjukkan bahwa penurunan tarif di India menyebabkan probabilitas menjadi pengangguran berkurang terutama bagi pekerja di sektor net exporter.

Selain menganalisis dampak liberalisasi perdagangan terhadap pengangguran di level sektoral, Hasan et al. (2012) juga menganalisis dampaknya terhadap pengangguran di level regional yaitu level state di India. Pengukuran tariff exposure di level state mengikuti pengukuran Topalova (2007). Tiap state dibedakan antara tariff exposure di daerah urban dan daerah rural serta tariffexposure pada state secara keseluruhan. Sektor non-tradable tidak dimasukkan ke dalam perhitungan tariff exposure-nya. Estimasi di level state menggunakan data ketenagakerjaan di India (NSSO) dari 15 state di India untuk tahun 1987-88, 1993-94, 1999-2000, dan 2004-05. Hasil estimasinya tidak membuktikan adanya hubungan antara tarif impor dan unemployment rate pada state secara keseluruhan. Akan tetapi, hasil estimasinya menemukan hubungan antara keduanya pada tipe-tipe state tertentu. Pada state yang memiliki pasar tenaga kerja yang lebih fleksibel, penurunan tarif berdampak pada penurunan unemployment rate, terutama pada daerah urban. Selain itu, penurunan tarif juga berdampak pada unemployment rate pada daerah urban di state yang memiliki alokasi pekerja yang besar di sektor net exporter. Hasan et al. (2012) juga menunjukkan dalam studinya bahwa penurunan tarif menyebabkan peningkatan pada unemployment dalam jangka pendek yang kemudian kembali menurun dan menuju steady-state.

Berbeda dengan studi Hasan et al. (2012) yang menggunakan data agregat unemployment rate untuk analisis dampak liberalisasi perdagangan di level regionalnya, studi Dix-Carneiro \& Kovak (2017) menganalisis dampaknya menggunakan data individu. Dengan menggunakan data ketenagakerjaan Brazil yang berasal dari RAIS, Dix-Carneiro \& Kovak mengestimasi dampak penurunan tarif terhadap pengangguran dalam dua tahap, seperti strategi empiris untuk estimasi upah industri dalam studi Attanasio et al. (2004) dan analisis level sektoral dari studi Hasan et al. (2012). Tahap pertama yaitu meregresikan persamaan status kerja individu ( 1 untuk tidak bekerja dan 0 untuk lainnya) tiap tahunnya dengan variabel kontrol karakteristik individu seperti umur, gender, tingkat pendidikan. Koefisien regional fixed effect dari hasil estimasi persamaan regresi pertama kemudian dijadikan sebagai variabel dependen pada persamaan regresi kedua dengan perubahan tarif 
dengan metode perhitungan Kovak (2013) sebagai variabel penjelasnya. Hasil estimasinya menunjukkan bahwa pengangguran di daerah yang lebih terekspos terhadap penurunan tarif impor akan mengalami peningkatan. Sama halnya dengan studi Hasan et al. (2012), Dix-Carneiro \& Kovak (2017) juga menemukan bahwa peningkatan pengangguran akibat penurunan tarif di Brazil akan menghilang dengan seiringnya waktu. Keduanya berpendapat bahwa pekerja yang mengalami displacement akibat penurunan tarif impor dan menjadi pengangguran dalam waktu yang lama akan pindah ke sektor informal. Hal tersebut sejalan dengan peningkatan pekerja di sektor informal dalam jangka waktu yang lama setelah penurunan tarif impornya. Studi keduanya ini juga menunjukkan bahwa dampak penurunan tarif impor di Brazil pada sektor non-tradable sama dengan dampaknya di sektor tradable.

\section{Metodologi}

\subsection{Pengukuran Regional Tariff Exposure di Level Kabupaten/Kota}

Oleh karena data tarif yang tersedia merupakan data level komoditi yang berlaku untuk nasional, maka kita perlu untuk membangun ukuran regional tariff exposure pada level kabupaten/kota. Sama dengan studi Hasan et al. (2012), ukuran regional tariff exposure dalam penelitian ini mengikuti strategi pengukuran Topalova (2007). Untuk itu, kami memanfaatkan informasi mengenai tarif di level 6-digit komoditi klasifikasi HS untuk diagregasi ke level 2-digit sektor klasifikasi ISIC Rev. 3 untuk tiap tahun analisis. Analisis penelitian ini menggunakan 30 sektor tradable yang mencakup sektor pertanian, pertambangan dan penggalian, serta sektor industri manufaktur. Informasi tarif di level sektoral ini kemudian digabungkan dengan data alokasi tenaga kerja di tiap sektornya pada level kabupaten/kota pada tahun awal analisis yaitu tahun 2000. Data alokasi tenaga kerja di tiap sektor pada level kabupaten/kota tersebut menjadi penimbang dari data tarif level sektornya. Adapun pengukurannya adalah sebagai berikut:

$$
\text { Tariff }_{d t}=\sum_{j=1}^{J}\left(\frac{L_{j d, t 0}}{L_{d, t 0}} \times \text { Tariff }_{j t}\right)
$$

dimana $j$ menunjukkan sektor tradable, $d$ menunjukkan kabupaten/kota, $\frac{L_{j d, t 0}}{L_{d, t 0}}$ merupakan alokasi tenaga kerja di sektor $j$ pada kabupaten/kota $d$ pada tahun 2000, Tariff ${ }_{j t}$ adalah tarif

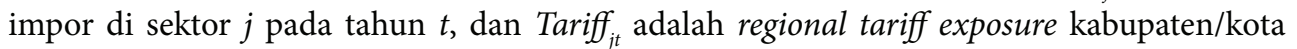
$d$ pada tahun $t$. Jumlah penimbang untuk seluruh sektor di suatu kabupaten/kota harus sama dengan satu, $\Sigma_{j}^{\frac{L_{j, t, 0}}{L_{a, 0}}}=1$. Sektor non-tradable tidak dilibatkan dalam perhitungan regional tariff exposure seperti dalam studi Kis-Katos \& Sparrow (2011, 2015), Hasan et al. (2012), dan Kovak (2013). Kovak berargumen bahwa sektor non-tradable dapat diabaikan dalam perhitungan karena harga produk non-tradable diperkirakan bergerak bersamaan dengan produk tradable. Ukuran regional tariff exposure di level kabupaten/kota ini diperkirakan dapat menggambarkan sensitifitas kabupaten/kota terhadap perubahan tarif impor. Regional tariff exposure yang tinggi untuk suatu kabupaten/kota berarti kabupaten/kota tersebut lebih terekspos terhadap penurunan tarif impor dibandingkan kabupaten/kota lainnya. 


\subsection{Model Ekonometrika}

Penelitian ini mengadopsi strategi Attanasio et al. (2004) untuk mengestimasi dampak penurunan tarif terhadap tingkat penganguran di level kabupaten/kota di Indonesia dengan melakukan regresi dua tahap. Strategi ini fokus pada pekerja dengan pengalaman kerja sebelumnya yang menjadi pengangguran. Akan tetapi, penelitian ini tidak mengikuti secara persis prosedur dalam Attanasio et al. (2004). Selain karena penelitian ini menganalisis di level regional, metode estimasi untuk persamaan regresi pertama dalam penelitian ini menggunakan restricted least square (RLS) untuk mengestimasi probabilitas menjadi pengangguran dengan constrained linear standard labor model dengan variabel dummy daerah, bukan dengan OLS seperti dalam studi Attanasio et al. (2004). Penelitian ini menggunakan RLS dengan alasan karena estimasi OLS pada modelnya dapat menimbulkan bias dalam interpretasi, meskipun kedua metode ini secara teknis tidak berbeda (Greene \& Seaks, 1991). Suits dalam Kennedy (1986) berargumen bahwa interpretasi variabel dummy yang lebih dari satu set akan aneh. Kita juga memerlukan koefisien dummy kabupaten/kota yang full rank agar tidak ada kabupaten/kota yang didrop karena dijadikan basis seperti dalam estimasi OLS. Dengan demikian, estimasi probabilitas menjadi pengangguran pada tahap pertama dalam penelitian ini dilakukan tiap tahun analisisnya dengan menggunakan persamaan sebagai berikut:

$$
\text { unemployed }_{i d t}=\alpha_{t}+\boldsymbol{\beta}_{1 t} \boldsymbol{X}_{i d t}+\gamma_{d t}+e_{i d t}
$$

s.t

$$
\sum_{d=1}^{D} w_{d t} \cdot \gamma_{d t}=0
$$

dimana unemployed ${ }_{i d t}$ merupakan variabel indikator untuk pekerja- $d$ di kabupaten/ kota- $d$ pada tahun- $t$. Variabel ini bernilai 1 untuk pengangguran yang pernah bekerja/ berhenti bekerja pada tahun sebelumnya dan bernilai 0 untuk lainnya. $\boldsymbol{X}_{\text {idt }}$ menangkap karakteristik individu seperti umur, dummy untuk pekerja laki-laki, pekerja di rural, dan variabel indikator mengenai status pendidikan pekerja. $\gamma_{d t}$ adalah dummy untuk kabupaten/ kota. $e_{i d t}$ adalah error term yang terdistribusi sama dan saling independen. Persamaan (7) ini diregresi secara terpisah tiap tahun analisis. $w_{d t}$ adalah penimbang di kabupaten/kota- $d$ pada tahun-t. Penimbangnya dihitung berdasarkan share pekerja di suatu kabupaten/kota terhadap angkatan kerjanya. Dengan demikian, jumlah dari seluruh penimbangnya pada tahun- $t$ sama dengan satu $\left(\sum_{d=1}^{D} w_{d t}=1\right)$.

Koefisien dummy kabupaten/kota dari hasil estimasi tahap pertama diinterpretasi sebagai resiko menjadi pengangguran di suatu kabupaten/kota relatif terhadap resiko rata-rata kabupaten/kota-nya. Koefisien ini kemudian dijadikan variabel dependen untuk persamaan regresi tahap kedua yang akan diestimasi dengan metode weighted least square (WLS) dengan varians hasil estimasi tahap pertama sebagai penimbang. Persamaan regresi tahap keduanya adalah sebagai berikut:

$$
\begin{aligned}
\gamma_{d t}=\alpha_{1}+\beta_{2} & \text { Tariff }_{d t-1}+\beta_{3} \text { Tariff }_{d t-1} * \text { ENM }_{d t}+\beta_{4} \text { ENM }_{d t}+\beta_{5} \ln \text { size }_{d t} \\
& +\beta_{6} \text { newent }_{d t}+\beta_{7} \ln \text { wage }_{d t}+\lambda_{t}+\eta_{d t}
\end{aligned}
$$


dimana $\gamma_{d t}$ adalah resiko menjadi kabupaten/kota di suatu kabupaten/kota- $d$ relatif terhadap resiko rata-rata kabupaten/kota pada tahun-t, Tariff jt adalah regional tariff exposure yang di-lag satu tahun, $\boldsymbol{E N M}_{i t}$ adalah alokasi pekerja pada sektor net importer di kabupaten/kota- $d$ pada waktu- $t$, size $e_{i t}$ adalah size perusahaan lokal di kabupaten/

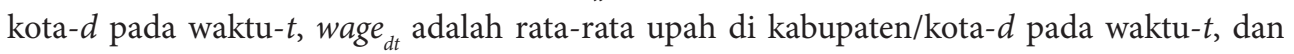
newent $_{d t}$ adalah jumlah perusahaan baru di kabupaten/kota- $d$ pada waktu- $t, \lambda_{t}$ adalah variabel dummy tahun untuk menangkap peran makroekonomi yang dapat mempengaruhi resiko menjadi kabupaten/kota di suatu kabupaten/kota relatif terhadap rata-ratanya tiap tahunnya, dan $n_{d t}$ adalah error term yang independen dan terdistribusi sama.

Persamaan regresi (8) menggunakan variabel $\boldsymbol{E N M}_{i t}$ yang merupakan alokasi pekerja di sektor net importer di tiap kabupaten/kota pada tahun. Variabel ini untuk mengontrol interaksinya dengan variabel regional tariff exposure. Variabel interaksi ini digunakan untuk menangkap perbedaan dampak penurunan tarif impor pada resiko relatif menjadi pengangguran antar kabupaten/kota. Dengan demikian, dampak dari penurunan tarif terhadap resiko menjadi pengangguran di suatu kabupaten/kota relatif terhadap rata-ratanya dapat dilihat dari marginal effect dari variabel regional tariff exposure terhadap resiko relatif menjadi pengangguran yaitu $\beta_{2}+\beta_{3}{ }^{*} \boldsymbol{E} \boldsymbol{N} \boldsymbol{M}_{i t}$. Term pertama merupakan dampak langsung tarif pada resiko menjadi pengangguran di suatu kabupaten/kota relatif terhadap rata-ratanya, sementara term kedua menangkap perbedaan dampak dari tarif berdasarkan struktur tenaga kerja di tiap kabupaten/kota. Berdasarkan relasi (5), term pertama diperkirakan bertanda negatif $\left(\beta_{2}<0\right)$. Selain itu, kabupaten/kota dengan alokasi tenaga kerja yang besar pada sektor yang paling terekspos terhadap penurunan tarif impor diperkirakan akan mengalami peningkatan resiko relatif menjadi pengangguran yang lebih tinggi. Dengan demikian, koefisien variabel interaksi dalam modelnya diperkirakan akan bertanda negatif $\left(\beta_{3}<0\right)$. Agar hubungannya konsisten, maka koefisien variabel $\beta_{1}>0$ diperkirakan akan betanda positif $\left(\beta_{1}>0\right)$ yang berarti semakin besar alokasi pekerja di sektor net importer pada suatu kabupaten/ kota, semakin tinggi juga resiko relatif menjadi pengangguran di kabupaten/kota tersebut.

Sementara itu, size ${ }_{i t}$, newent ${ }_{d t}$, and wage $e_{d t}$ merupakan variabel untuk mengontrol dampak penurunan tarif pada barang input yang tidak diproduksi oleh perusahaan lokal. size $_{\text {it }}$ merupakan size perusahaan yang didekati dengan jumlah pekerja di kabupaten/ kota $i$ pada tahun $t$. Variabel ini mengontrol pergeseran permintaan tenaga kerja yang terjadi ketika perusahaan melakukan ekspansi usahanya akibat peningkatan profit dari biaya input yang lebih murah. newent dt merupakan jumlah perusahaan lokal baru yang masuk ke pasar di tiap kabupaten/kota $i$ pada tahun $t$. Variabel ini mengontrol pergeseran permintaan tenaga kerja yang terjadi ketika peningkatan profit akibat biaya input yang lebih murah dapat menarik perusahaan-perusahaan baru masuk ke pasar. Sementara itu, wage $e_{d t}$ merupakan rata-rata upah di kabupaten/kota $i$ pada tahun $t$, yang mengontrol pergeseran pada permintaan tenaga kerja yang terjadi ketika pemerintah menaikkan upah yang dibayarkan untuk pekerjanya yang disebabkan peningkatan profitnya.

Seperti yang telah dijelaskan sebelumnya, penurunan tarif input dapat meningkatkan pada sektor dimana perusahaan-perusahaan lokal menggunakan produk impor sebagai input produksinya. Peningkatan profit tersebut dapat menyebabkan size sektor ini menjadi lebih besar karena perusahaan-perusahaannya melakukan ekspansi serta dapat menarik perusahaanperusahaan lokal baru untuk masuk ke pasar. Kedua kondisi tersebut akan menyebabkan 
penurunan pada tingkat pengangguran di sektor ini. Dengan demikian, koefisien variabel size dan new entrants diperkirakan akan bertanda negatif $\left(\beta_{5}<0 ; \beta_{6}<0\right)$. Sementara itu, peningkatan profit perusahaan juga dapat mendorong perusahaan menaikkan upah yang dibayarkan untuk pekerja. Hal ini dapat menyebabkan peningkatan pada employment dan pengangguran menurun. Dengan demikian, koefisien variabel wage diperkirakan juga akan bertanda negatif $\left(\beta_{7}<0\right)$. Tanda negatif pada ketiga variabel ini secara tidak langsung dapat menunjukkan bahwa penurunan tarif input terhadap tingkat pengangguran di level kabupaten/kota.

Kebijakan tarif impor diperkirakan dapat menimbulkan endogenitas yang disebabkan karena dual causality dengan kondisi perekonomian. Teori ekonomi menunjukkan bahwa kondisi perekonomian dapat mempengaruhi timing dari perubahan tarif dan bagaimana pola proteksi antar sektor (Goldberg \& Pavcnik, 2016). Akan tetapi, hubungan dual causality tersebut agak kurang relevan untuk regional tariff exposure di level kabupaten/ kota. Penggunaan lag pada variabel regional tariff exposure pada persamaan estimasinya diharapkan dapat mengontrol endogenitas tersebut. Sementara itu, endogenitas tetap berpotensi menjadi masalah yang disebabkan measurement error. Mengingat ukuran regional tariff exposure dalam penelitian ini mengikut strategi pengukuran Topalova dan masih ada strategi pengukuran lain yang sepertinya lebih precise yaitu strategi Kovak, tentunya masalah measurement error mungkin saja terjadi. Jika dibandingkan dengan ukuran regional tariff exposure dalam studi Inggriyani (2016) yang mengikuti strategi pengukuran Kovak pada tahun sampel yang sama dengan penelitian ini (tahun 2000 dan 2008), tidak ada perbedaan yang berarti pada pola regional tariff exposure tiap tahunnya. Selain itu, endogenitas juga dapat disebabkan oleh omitted variable bias. Salah satu contohnya adalah tidak dilibatkannya variabel non-tarif di dalam persamaan estimasi yang mungkin saja berpengaruh pada tingkat pengangguran. Akan tetapi, masuknya variabel non-tarif ke dalam persamaannya juga dapat menimbulkan multikolinearitas akibat korelasi positif antara tarif dan non-tarif. Meskipun demikian, penelitian ini tetap melakukan robustness check untuk menguji konsistensi hasil estimasi tanpa mengontrol endogenitas dan hasil estimasi yang mengontrol endogenitas yang disebabkan oleh measurement error dan omitted variable bias (menggunakan first difference estimator).

\subsection{Data}

Penelitian ini menggunakan data panel dengan unit cross-section kabupaten/kota di Indonesia selama periode 2000-2013. Kabupaten/kota yang dijadikan unit analisis dalam penelitian ini berdasarkan kondisi administrasi wilayah di tahun 1999. Setelah membuang kabupaten/kota yang tidak memiliki data pekerja di tahun 2000, total kabupaten/kota yang dijadikan sampel menjadi 297 kabupaten/kota. Informasi mengenai data ketenagakerjaan secara agregat seperti alokasi pekerja tiap sektor diperoleh dari data Sakernas tahun 2000, 2001, 2005, 2009, dan 2013. Data alokasi pekerja tiap sektor pada tahun 2000 diperlukan dalam pengukuran regional tariff exposure. Oleh karena data Sakernas belum representatif untuk estimasi kabupaten/kota, penelitian ini menggunakan inflation factor dalam pengukuran data agregat alokasi tenaga kerja di level sektor. Sementara itu, informasi mengenai data individu seperti status pekerjaan saat ini, pengalaman kerja, serta karakteristik individu seperti umur, kuadrat umur, jenis kelamin, tempat tinggal (rural/urban), dan tingkat pendidikan. Sampel dalam estimasi pendekatan individu ini dibatasi untuk responden berumur 15 tahun ke atas, 
termasuk angkatan kerja, dan memiliki pengalaman kerja (pernah bekerja, berhenti kerja, atau pindah kerja dalam setahun terakhir). Sampel yang tidak memenuhi kriteria tidak dilibatkan dalam estimasi. Informasi mengenai tarif, ekpor dan impor diperoleh dari database World Integrated Trade Solution (WITS) pada tahun 2000, 2004, 2008, dan tahun 2012. Oleh karena data tarif yang tersedia merupakan data tarif level komoditi 6 digit HS, maka perlu dilakukan agregasi dan konkordasi ke level sektor 2 digit klasifikasi ISIC Rev. 3. Penggunaan level agregasi sektor 2 digit ISIC Rev. 3 adalah untuk menyesuaikan data ketenagakerjaan yang digunakan dalam penelitian ini. Sektor yang dilibatkan dalam analisis penelitian ini ada 30 sektor tradable mencakup sektor pertanian, pertambangan dan penggalian, serta sektor industri manufaktur. Informasi mengenai nilai ekspor dan impor digunakan untuk menentukan sektor net importer. Suatu sektor dikategorikan sebagai sektor net importer jika nilai net export-nya kurang dari nol. Sementara itu, informasi mengenai jumlah pekerja yang digunakan untuk mendekati size, rata-rata upah, dan jumlah perusahaan baru di tiap kabupaten/kota diperoleh dari data Industri Besar dan Sedang (IBS). Hal ini tentunya menjadi salah satu batasan penelitian ini dikarenakan data IBS hanya mencakup sektor industri manufaktur sementara penelitian ini juga mencakup sektor pertanian dan pertambangan.

\section{Hasil dan Analisis}

Tabel 1 menyajikan hasil estimasi regresi tahap pertama tiap tahun analisis yang digunakan untuk menghasilkan resiko menjadi pengangguran di suatu kabupaten/kota relatif terhadap resiko rata-rata kabupaten/kota-nya. Secara rata-rata, hasil estimasi pada Tabel 1 menunjukkan bahwa probabilitas menjadi pengangguran lebih besar pada pekerja muda, yang tinggal di daerah perkotaan, dan pekerja yang kurang berpendidikan. Semakin bertambahnya umur pekerja, probabilitasnya menjadi pengangguran akan menurun. Akan tetapi, probabilitasnya untuk menjadi pengangguran akan meningkat ketika umurnya melebihi 60 tahun. Sementara itu, probabilitas pekerja laki-laki untuk menjadi pengangguran dibandingkan probabilitasnya pekerja perempuan. Hal ini mungkin dikarenakan pekerja perempuan terutama yang sudah berkeluarga dan memiliki anak lebih banyak terserap di sektor informal yang cenderung lebih fleksibel jam kerjanya. Koefisien kabupaten/kota dari hasil regresi tahap pertama tidak dapat ditampilkan dalam Tabel 1 dikarenakan membutuhkan space yang banyak. 
Tabel 1. Hasil Regresi Tahap Pertama Strategi Pendekatan Individu

\begin{tabular}{lllll}
\hline \multicolumn{1}{c}{ Variables } & \multicolumn{1}{c}{2001} & \multicolumn{1}{c}{2005} & \multicolumn{1}{c}{2009} & 2013 \\
\hline Constant & $0,05532^{* * *}$ & $0,03076^{* * *}$ & $0,07317^{* * *}$ & $0,12538^{* * *}$ \\
& $(0,00554)$ & $(0,00399)$ & $(0,00543)$ & $(0,00688)$ \\
Age & $-0,00263^{* * *}$ & $-0,00139^{* * *}$ & $-0,00233^{* * *}$ & $-0,00374^{* * *}$ \\
& $(0,00024)$ & $(0,00017)$ & $(0,00010)$ & $(0,00015)$ \\
Age squared & $0,00002^{* * *}$ & $0,00001^{* * *}$ & $0,00001^{* * *}$ & $0,00002^{* * *}$ \\
& $(0,000003)$ & $(0,000002)$ & $(0,000001)$ & $(0,000002)$ \\
Male & $0,00954^{* * *}$ & $0,00599^{* * *}$ & $0,01836^{* * *}$ & $0,01865^{* * *}$ \\
& $(0,00134)$ & $(0,00093)$ & $(0,00054)$ & $(0,00077)$ \\
Rural & $-0,00437^{* *}$ & $-0,00758^{* * *}$ & $-0,00575^{* * *}$ & $-0,00596^{* * *}$ \\
& $(0,00182)$ & $(0,00134)$ & $(0,00080)$ & $(0,00095)$ \\
Secondary education & $0,00435^{* * *}$ & $0,00532^{* * *}$ & $0,00280^{* * *}$ & $0,00176^{*}$ \\
& $(0,00166)$ & $(0,00114)$ & $(0,00066)$ & $(0,00094)$ \\
Tertiary education & 0,00500 & 0,00772 & $-0,00995^{* * *}$ & $-0,02166^{* * *}$ \\
& $(0,00330)$ & $(0,00228)$ & $(0,00108)$ & $(0,00127)$ \\
observation & 66.453 & 108.189 & 509.508 & 318.093 \\
probability of F statistic & 0,00000 & 0,00000 & 0,00000 & 0,00000 \\
F statistic & 6,62 & 8,37 & 48,37 & 40,06 \\
\hline
\end{tabular}

Keterangan: Variabel dependennya bernilai 1 untuk pengangguran yang memiliki pengalaman kerja sebelumnya, dan bernilai 0 untuk lainnya. Nilai absolut dari robust t-statistics berada dalam kurung siku. Pendidikan primer sebagai acuan untuk variabel indikator pendidikan. Variabel dummy kabupaten/kota tidak ditampilkan.

* Signifikan pada level $10 \%$

** Signifikan pada level $5 \%$

*** Signifikan pada level $1 \%$

Hasil estimasi dari regresi tahap kedua disajikan pada Tabel 2. Hasil estimasi pada kolom 1 dan 2 di Tabel 2 belum dapat membuktikan adanya hubungan negatif antara regional tariff exposure dan resiko relatif menjadi pengangguran level kabupaten/ kota. Koefisien regional tariff exposure pada kolom 1 dan 2 bertanda negatif tapi tidak signifikan. Meski koefisien dari variabel kontrol alokasi pekerja di sektor net importer (ENM) bertanda positif dan signifikan, tetapi koefisien variabel interaksi antara regional tariff exposure dan alokasi pekerja di sektor net importer (L.Tariffs ${ }^{\star}$ ENM) tidak signifikan.

Setelah menambah variabel kontrol size, new entrants, dan wage, hasil estimasi pada kolom 3 di Tabel 2 baru menunjukkan adanya efek peningkatan resiko relatif menjadi pengangguran di suatu kabupaten/kota akibat penurunan tarif impor. Meski koefisien variabel regional tariff exposure tidak signifikan, tapi variabel interaksinya dengan variabel alokasi pekerja di sektor net importer bertanda negatif dan signifikan pada level $10 \%$. Hal ini berarti bahwa penurunan tariff exposure dapat menyebabkan peningkatan pada resiko relatif menjadi pengangguran di suatu kabupaten/kota dan peningkatannya akan lebih besar pada kabupaten/ kota yang memiliki alokasi pekerja lebih besar pada sektor net importer. Koefisien variabel kontrol alokasi pekerja di sektor net importer bertanda positif dan signifikan pada level 1\% yang berarti semakin besar alokasi pekerja suatu kabupaten/kota pada sektor net importer, semakin tinggi juga resiko relatif menjadi pengangguran di kabupaten/kota tersebut. 
Tabel 1. Hasil Regresi Tahap Kedua Strategi Pendekatan Individu

\begin{tabular}{|c|c|c|c|}
\hline Variables & 1 & 2 & 3 \\
\hline \multirow[t]{2}{*}{ Constant } & $0,03198^{* * *}$ & 0,002386 & $0,24932^{\star * *}$ \\
\hline & {$[24,28]$} & $(0,00160)$ & $(0,02032)$ \\
\hline \multirow[t]{2}{*}{ L.Tariffs } & $-0,00474$ & $-0,00139$ & $-0,00019$ \\
\hline & $(0,00328)$ & $(0,00090)$ & $(0,00044)$ \\
\hline \multirow[t]{2}{*}{ L.Tariffs ${ }^{\star}$ ENM } & & $-0,00118$ & $-0,00179^{*}$ \\
\hline & & $(0,00079)$ & $(0,00104)$ \\
\hline \multirow[t]{2}{*}{ ENM } & & $0,16359^{* * *}$ & $0,10813^{\star * *}$ \\
\hline & & $(0,00497)$ & $(0,02054)$ \\
\hline \multirow[t]{2}{*}{ Ln Size } & & & $-0,00190^{* *}$ \\
\hline & & & $(0,00037)$ \\
\hline \multirow[t]{2}{*}{ New Entrants } & & & $-0,00009^{\star * *}$ \\
\hline & & & $(0,00002)$ \\
\hline \multirow[t]{2}{*}{ Ln Wage } & & & $-0,01565^{\star * *}$ \\
\hline & & & $(0,00115)$ \\
\hline Obs & 1167 & 1167 & 1167 \\
\hline Number of districts & 297 & 297 & 297 \\
\hline \multirow[t]{2}{*}{ R-squared } & 0,3112 & 0,6517 & 0,7018 \\
\hline & 0,3088 & 0,6499 & 0,6995 \\
\hline
\end{tabular}

Keterangan: Variabel dependennya adalah resiko menjadi pengangguran di suatu kabupaten/kota relatif terhadap resiko rata-rata kabupaten/kotanya. Robust standard errors berada dalam tanda kurang. Variabel dummy tahun termasuk sebagai variabel independennya tetapi tidak ditampilkan dalam tabel (2001 sebagai tahun acuan).

* Signifikan pada level 10\%

** Signifikan pada level $5 \%$

*** Signifikan pada level $1 \%$

Sementara itu, koefisien untuk ketiga variabel kontrol dampak penurunan tarif input bertanda negatif dan signifikan. Secara tidak langsung, hasil estimasi pada kolom 3 di Tabel 2 ini mengindikasi bahwa penurunan tarif input dapat menyebabkan penurunan pengangguran, meskipun efeknya sangat kecil. Setiap peningkatan jumlah pekerja di suatu kabupaten/kota sebesar satu persen akan menurunkan resiko relatif menjadi pengangguran di kabupaten/ kota tersebut sebesar 0,00002, ceteris paribus. Setiap ada satu perusahaan baru yang masuk ke pasar di suatu kabupaten/kota, resiko relatif menjadi pengangguran di kabupaten/kota tersebut akan turun sebesar 0,00009, ceteris paribus.. Sementara itu, setiap kenaikan upah di suatu kabupaten/kota sebesar satu persen, resiko relatif menjadi pengangguran di kabupaten/ kota tersebut akan turun sebesar $0,0002 \mathrm{p}$, ceteris paribus.

Hasil estimasi dengan first difference tidak berbeda jauh dari hasil estimasi persamaan dasar sebelum mengontrol endogenitas yang disebabkan measurement error dan omitted variable bias. Meskipun koefisiennya lebih kecil, hasil estimasinya juga menunjukkan hubungan negatif antara regional tariff exposure dan resiko relatif menjadi pengangguran di suatu kabupaten/kota, setelah mengontrol dampak positif dari tarif impor pada barang input. Dengan demikian, hasil yang diperoleh dari persamaan dasar, yaitu hasil regresi tahap kedua, tetap konsisten meskipun belum mengontrol endogenitas, baik yang disebabkan measurement error maupun omitted variable bias

Berdasarkan hasil estimasi penelitian ini, dapat disimpulkan bahwa penurunan tarif 
impor dapat menyebabkan peningkatan tingkat pengangguran, tentunya setelah mengontrol dampak penurunan tarif input. Peningkatannya lebih besar pada kabupaten/kota yang lebih besar pada sektor yang lebih terekspos terhadap penurunan tarif yaitu sektor net importer. Hasil penelitian ini sejalan dengan temuan dalam studi Dix-Carneiro \& Kovak (2017) yang menemukkan bahwa daerah yang paling terekspos terhadap penurunan tarif yang terjadi di Brazil mengalami peningkatan pengangguran yang lebih besar dibandingkan daerah lainnya.

Sementara itu, hasil penelitian ini agak berbeda dengan hasil studi Hasan et al. (2012) yang belum dapat membuktikan adanya efek peningkatan pengangguran dari penurunan tarif di India. Hal ini tentunya tidak sesuai dengan argumennya yang mengatakan bahwa penurunan tarif diduga akan meningkatkan pengangguran, setidak dalam jangka pendek. Meski variabel interaksinya menunjukkan bahwa state dengan pasar tenaga kerja yang lebih fleksibel atau yang memiliki alokasi pekerja lebih besar pada sektor net exporter akan mengalami penurunan pengangguran, tidak signfikannya variabel regional tariff exposure membuat dampak secara keseluruhannya positif. Hal ini diduga karena studi Hasan et al. (2012) belum mengontrol dampak penurunan tarif input sehingga dampak penurunan tarif secara keseluruhan (tarif output) pada persamaan estimasinya. Penelitian ini secara tidak langsung membuktikan bahwa penurunan tarif input memang berpengaruh pada dampak penurunan tarif secara keseluruhan dimana dampaknya adalah penurunan tingkat pengangguran.

\section{Kesimpulan}

Penelitian ini mengestimasi dampak penurunan tarif terhadap tingkat pengangguran di level kabupaten/kota pada periode 2000-2013. Pengukuran regional tariff exposure di level kabupaten/kota mengikuti strategi Topalova (2007). Pengangguran dalam penelitian ini diukur dengan pendekatan data individu yang diukur dengan resiko menjadi pengangguran di suatu kabupaten/kota relatif terhadap rata-rata kabupaten/kota. Setelah mengontrol pergeseran permintaan tenaga kerja akibat penurunan tarif input, penelitian ini membuktikan bahwa penurunan tarif menyebabkan peningkatan pada tingkat pengangguran, baik secara pendekatan agregat maupun pendekatan individu, dan peningkatannya tersebut lebih besar pada kabupaten/kota yang memiliki alokasi pekerja yang lebih besar di sektor yang lebih terekspos terhadap penurunan tarif. Penelitian ini secara tidak langsung menemukan adanya penurunan pada tingkat pengangguran akibat penurunan tarif input.

Penelitian memiliki keterbatasan data khususnya terkait data ketenagakerjaan dimana data yang digunakan pada dasarnya belum representatif untuk melakukan estimasi di level kabupaten/kota. Untuk itu, penelitian selanjutnya diharapkan dapat menggunakan data yang lebih baik sehingga hasil estimasi yang didapatkan juga dapat lebih baik lagi. Selain itu, variabel yang digunakan untuk mengontrol dampak penurunan tarif pada perusahaan-perusahaan lokal yang menggunakan produk impor sebagai input produksinya dalam penelitian ini bersumber dari data industri besar dan sedang dari BPS yang hanya mencakup sektor manufaktur. Sementara itu, penelitian ini tidak hanya mencakup sektor manufaktur tetapi juga sektor tradable non manufaktur. Hal ini tentunya kurang mewakili kondisi sebenarnya. Oleh karena itu, penelitian selanjutnya diharapkan dapat menggunakan data yang lebih representatif untuk variabel kontrolnya agar dapat memperkecil kesalahan pengukuran dan mendapatkan hasil estimasi yang lebih akurat. 
Penelitian ini fokus pada dampak dari penurunan tarif impor sebagai indikator liberalisasi perdagangan di Indonesia. Sementara itu, terdapat beberapa kebijakan perdagangan lainnya yang diterapkan pemerintah Indonesia untuk melindungi produk domestik, seperti kebijakan non tarif. Akan tetapi, kebijakan non tarif lebih sulit diukur dibandingkan kebijakan tarif impor. Jika ingin mulai menganalisis dampak dari kebijakan non tarif atau kombinasi dari tarif dan non tarif dapat mempelajari studi Hasan et al. (2012) dengan menggunakan kerangka konseptual di dalamnya.

Penelitian ini menemukan bahwa penurunan tarif impor berdampak pada peningkatan pengangguran selama periode observasi 2000-2013. Beberapa studi sebelumnya dalam literatur dampak dari liberalisasi perdagangan menemukan bahwa liberalisasi perdagangan juga dapat menyebabkan peningkatan employment di sektor informal dalam jangka panjang seperti dalam studi Dix-Carneiro \& Kovak (2017). Keduanya berargumen bahwa pekerja yang mengalami displacement dan menjadi pengangguran akibat penurunan tarif seiringnya waktu akan pindah ke sektor informal atau bahkan keluar dari pasar tenaga kerja. Hal ini dapat menjadi isu untuk penelitian selanjutnya. Selain itu, penelitian ini menganalisis dampak penurunan tarif impor terhadap pengangguran secara keseluruhan. Jika ingin meneliti perbedaan dampaknya berdasarkan karakteristik pekerja seperti tingkat pendidikan dapat mempelajari studi Autor et al. (2013).

\section{Daftar Pustaka}

Attanasio, O., Goldberg, P. K., \& Pavcnik, N. (2004). Trade reforms and wage inequality in Colombia. Journal of Developing Economics, 74, 331-366. https://doi.org/10.1016/j. jdeveco.2003.07.001

Autor, D. H., Dorn, D., \& Hanson, G. H. (2013). The China syndrome: Local labor market effects of import competition in the United States. American Economic Review. https:// doi.org/10.1257/aer.103.6.2121

Casacuberta, C., \& Gandelman, N. (2006). Protection, Opennes and Factor Adjustment: Evidence from The Manufacturing Sector in Uruguay. World Bank Policy Research Working Paper.

Dix-Carneiro, R., \& Kovak, B. K. (2017). Margins of Labor Market Adjustment to Trade (NBER Working Paper 23595). Retrieved from http://www.nber.org/papers/w23595

Dutt, P., Mitra, D., \& Ranjan, P. (2009). International trade and unemployment: Theory and cross-national evidence. Journal of International Economics, 78(1), 32-44. https://doi. org/10.1016/j.jinteco.2009.02.005

Ebenstein, A., Harrison, A., McMillan, M., \& Phillips, S. (2009). Estimating the impact of trade and offshoring on American workers using the current population surveys. NBER Working Paper Series.

Goldberg, P. K., \& Pavcnik, N. (2016). The Effects of Trade Policy. NBER Working Paper, (21957).

Greene, W. H., \& Seaks, T. G. (1991). The Restricted Least Squares Estimator : A Pedagogical Note. The Review of Economics and Statistics, 73(3), 563-567. Retrieved from http:// www.jstor.org/stable/2109587

Hasan, R., Mitra, D., Ranjan, P., \& Ahsan, R. N. (2012). Trade liberalization and unemployment : Theory and evidence from India. Journal of Development Economics, 97(2), 
269-280. https://doi.org/10.1016/j.jdeveco.2011.04.002

Ihsanuddin, J. (2015). The Effect of Import Tariff Reduction on Unemployment in Indonesia. University of Indonesia.

Inggriyani, Y. (2016). Dampak Liberalisasi Perdagangan terhadap Probabilitas Anak Bekerja di Indonesia Tahun 2000-2008.

Kennedy, P. (1986). Interpreting Dummy Variables. The Review of Economics and Statistics, 68(1), 174-175. Retrieved from http://www.jstor.org/stable/1924943

Kis-Katos, K., \& Sparrow, R. (2011). Child Labor and Trade Liberalization in Indonesia Krisztina Kis-Katos Robert Sparrow. The Journal of Human Resources, 46(4), 722-749.

Kis-Katos, K., \& Sparrow, R. (2015). Poverty, Labour Markets and Trade Liberalization in Indonesia. Journal of Developing Economics, 117, 94-106. https://doi.org/https://doi. org/10.1016/j.jdeveco.2015.07.005

Kovak, B. K. (2013). Regional Effects of Trade Reform : What is the Correct Measure of Liberalization? American Economic Review, 103(5), 1960-1976.

Menezes-Filho, N. A., \& Muendler, M.-A. (2007). Labor Reallocation in Response to Trade Reform. CESIFO Working Paper No. 1936. Retrieved from http://www.cesifo-group. de/DocDL/cesifo1_wp1936.pdf

Muendler, M.-A. (2010). Trade Reform, Employment Allocation and Worker Flows. In G. Porto \& B. M. Hoekman (Eds.), Trade Adjustment Costs in Developing Countries: Impacts, Determinants and Policy Responses (pp. 103-141). World Bank and CEPR.

Pissarides, C. A. (2000). Equilibrium Unemployment Theory Second Edition.

Porto, G. (2008). Agro-Manufactured Export Prices, Wages and Unemployment. American Journal of Agricultural Economics, 90(3), 748-764.

Topalova, P. (2007). Trade Liberalization, Poverty and Inequality: Evidence from Indian Districts. In A. Harrison (Ed.), Globalization and Poverty (pp. 291-335). University of Chicago Press. Retrieved from http://www.nber.org/books/harr06-1

Topalova, P. (2010). Factor Immobility and Regional Effects of Trade Liberalization: Evidence from India. American Economic Journal: Applied Economics, 2, 1-41. https://doi. org/10.1257/app.2.4.1 